Y. B. Bedrina

\title{
THE PROBLEMS OF THE PROVIDING THE REGIONS WITH HEALTH CARE INFRASTRUCTURE IN CONDITIONS OF INCREASE OF MIGRATORY MOBILITY
}

Subject matter of the article is a question of the providing the newcomers to regions of the Russian Federation with healthcare infrastructure facilities. The purpose of the research is an assessment of level of this providing. On the basis of calculation of the integrated indicators of the development of health care infrastructure and the providing the population with healthcare infrastructure facilities the grouping of regions is carried out. By means of the two-dimensional analysis, we made a comparison of regions on indicators of arrival of the population and the above-named settlement indicators. The analysis of dynamics of the number change of healthcare infrastructure facilities during its reforming from 2005 to 2011 is performed. As a result of the research, the following conclusion is drawn: the level of investment into the regions as well as in its health care infrastructure do influence on the intensity of migratory flows, however, distribution of investments into health care facilities in regions does not take in to account the directions of migratory flows and poorly considers the population size of territories. This article may be interesting to the experts dealing with issues of development of regions.

Keywords: region, migration, health care, the providing the population with health care infrastructure

The development of health-care infrastructure does not take into account the attraction of territories to potential migrants. Available official standards are calculated on the basis of the population registration of the prior period. In the territories experiencing rather big migrant inflows, the 
disproportions in providing the population with healthcare infrastructure facilities are occurred with the passage of time. Prevalent way to solve this issue is to underestimate the actual data that lead to the deterioration of official norms from year to year. Such procedures conduct to the worsening of the living conditions of migrants, and local population.

In this research, the attempt to analyze the providing with the health care infrastructure the newcomers population to the territory of the Russian Federation is carried out.At the heart of the research lays the hypothesis that investment in healthcare infrastructure facilities is a condition for migratory movement. This hypothesis is formulated on the basis of thesis about a role of the social sphere in support of demographic safety, including «the abilities to resist the migration outflow of the population from territories and to support migration inflow within the permissible limits» [5, p.11].

In the analysis, the data on a number of migrants from Federal Public Statistics Service of the Russian Federation and the data on development of network and activity of healthcare institutions have been used [2].

At the initial stage, the calculation of territorial indexes was carried out according to the following all-Russian indicators: a) number of people arrived; b) the number of outpatient clinics; $c$ ) the number of hospital beds; $d$ ) the number of medical institutions; e) the number of first-aid stations; e) the number of institutions providing medical assistance to the population:

$$
I_{i}=K_{i}^{r} / K_{i}^{R F},
$$

where $I_{i}-$ an index of $i$ indicator; $K_{i}^{r}, K_{i}^{R F}$ - the $\mathrm{i}$ indicator of region and the Russian Federation.

Since the activity of healthcare institutions is presented in the state reports by five indicators, we have offered the integrated index of development of health care infrastructure (2).

As an index of development of health care infrastructurethe average indicator was chosen:

$$
I_{d h i}=\frac{I_{1}+I_{2}+I_{3}+I_{4}+I_{5}}{5},
$$

Where $I_{d h i}-$ an index of development of health careinfrastructure; $I_{1}-$ an index of outpatient clinics; $I_{2}-$ an index of hospital beds; $I_{3}-$ an index of hospitals; $I_{4}-$ an index of first-aid stations; $I_{5}-$ an index of the institutions providing medical assistance to the population.

Then the two-dimensional group of regions of the Russian Federation on indicators of of people arrived and development of the healthcare sphere for 2011 was made (tab. 1).

As shown in Table 1, only 10 regions in 2011 experienced the majority of the migrant inflows, i. e. Republic of Bashkortostan and Tatarstan, Krasnoyarsk territory, the Moscow, Sverdlovsk, Tyumen and Novosibirsk areas, Moscow and St. Petersburg. Moreover, another 18 territories experienced migration above an average; the others 55 were not unattractive to migrants. The regions not attractive to migrants are the regions of the Far East Federal district of little use for accommodation, and the regions enabled to withstand competition to more developed neighbors. Besides, the majority of such regions were located in the Central and North Western Federal districts - 14 and 10, respectively. The Moscow region 0,068 (Moscow - 0,037) had the highest index of arrival of the population, and Chukot Autonomous Area, Nenets Autonomous Area, and the Jewish Autonomous Region had the lowest one - 0,001.

The analysis of distribution of investments into health care facilities revealed some inequality, i.e. the number of regions having higher index of development of health care infrastructure was slightly less of the number of regions having lower index (35 and 48 accordingly). Moscow and the Moscow region -0.073 and 0.040 , respectively had the highest indexes of development of health care infrastructure, but the Chukot and Nenets Autonomous Areas - 0.001, and also the Republic of Ingushetia -0.002 had the lowest ones.

However, as a result, there was rather harmonious picture concerning the correspondence of intensity of migrant flows and development of health care infrastructure (agreement in indexes took place in 61 regions). Therefore, the better region is developed including health care infrastructure, the more it is attractive to migration.

The imbalance of in the ratio of calculated indexes took place only in 22 regions. These regions can be divided into two groups. The first group includes 15 regions where the index of development of the healthcare sphere is higher than the index of the arrival of the population. In turn, they fall into two types of regions: 1 ) the regions are not attractive to migration (the index of the population arrived is lower than an average) - The Volgograd region, Tula region, the Arkhangelsk region, the Republic of Dagestan, etc.; 2) and the attractive ones (the index of the population arrived is higher than an average) - the Rostov region, the Nizhny Novgorod region. In the second group where the index of development of the health care infrastructure was lower than an arrival index were included 7 regions. These are regions with a high 
$\frac{\overrightarrow{0}}{\text { चี }}$

\begin{tabular}{|c|c|c|c|c|}
\hline لـ & 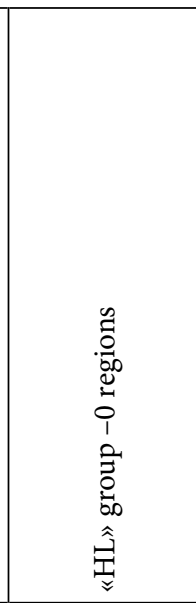 & 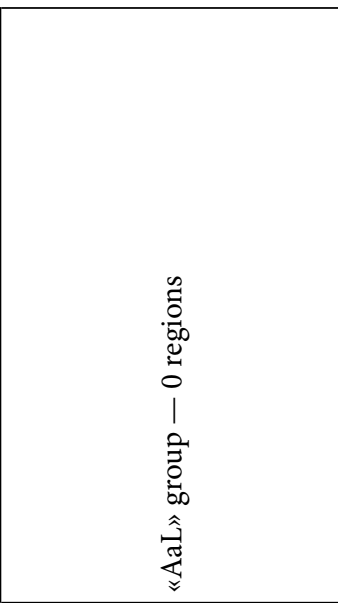 & 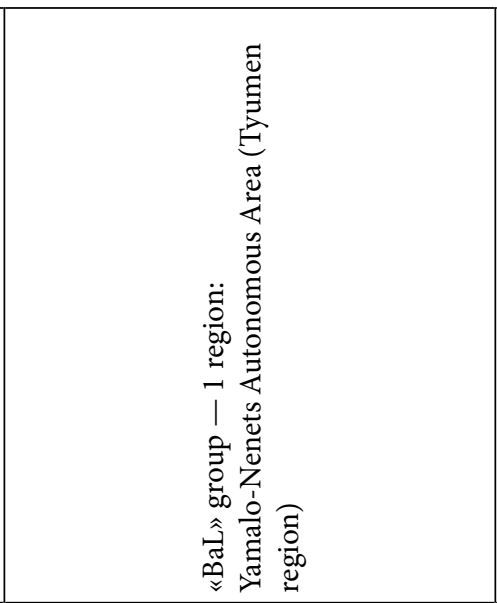 & 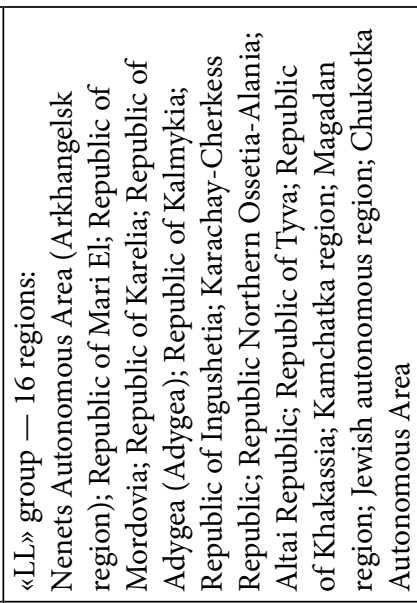 \\
\hline 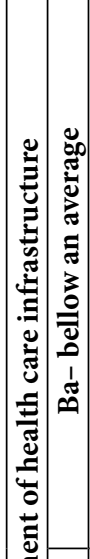 & 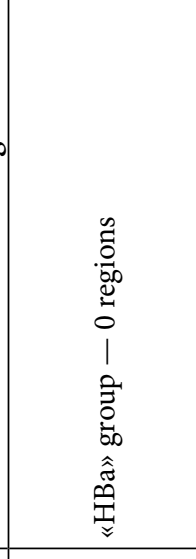 & 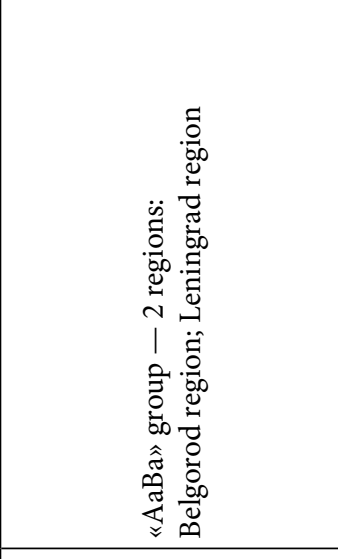 & 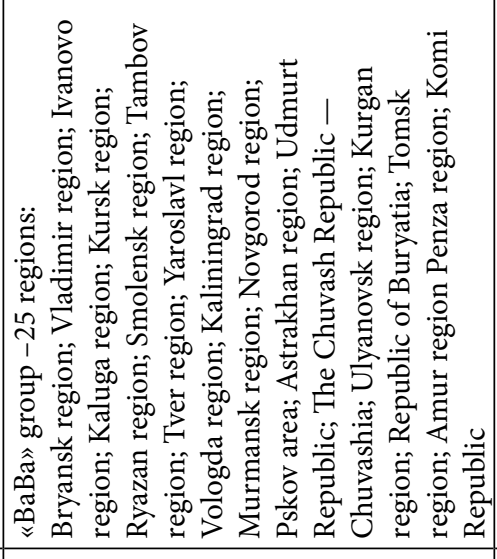 & 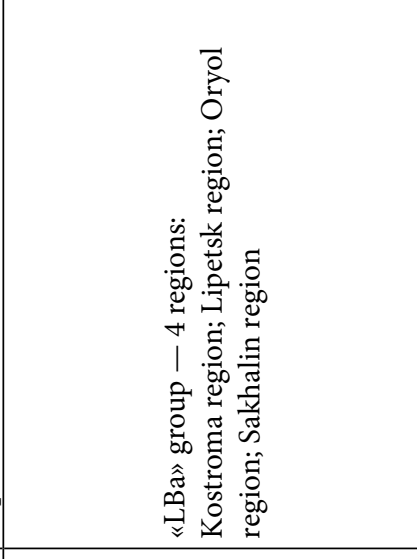 \\
\hline 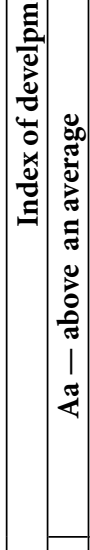 & 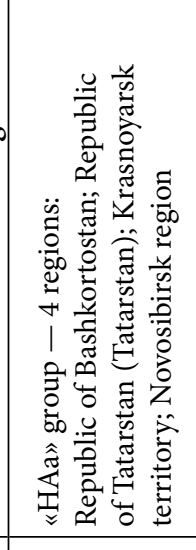 & 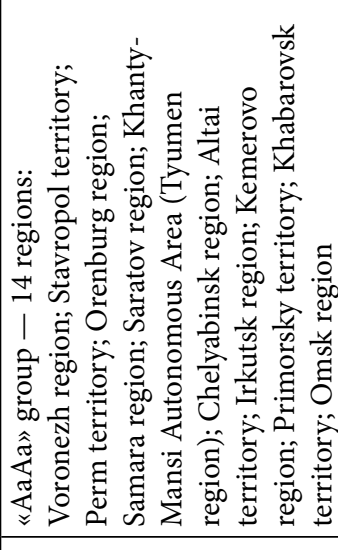 & 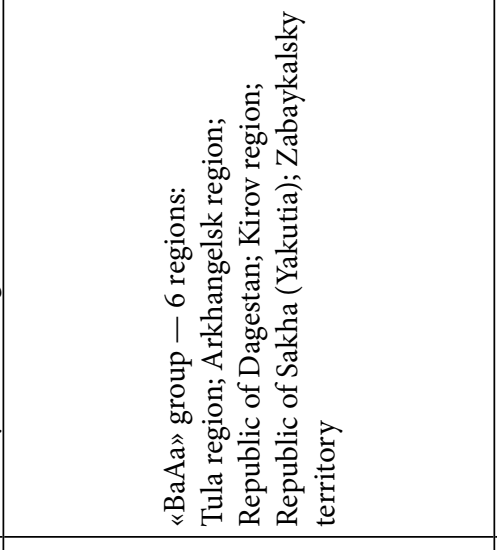 & 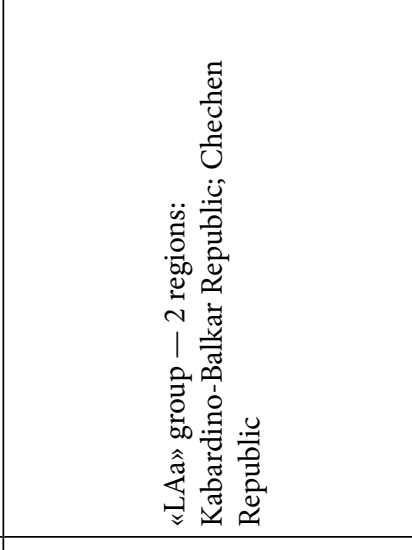 \\
\hline $\begin{array}{l}5 \\
0 \\
1 \\
0 \\
0\end{array}$ & 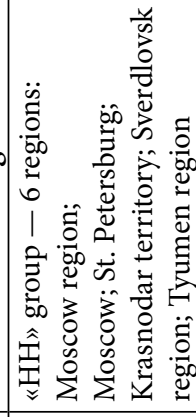 & 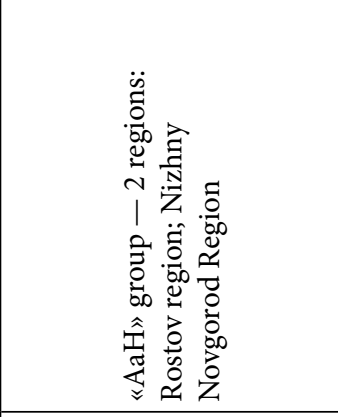 & 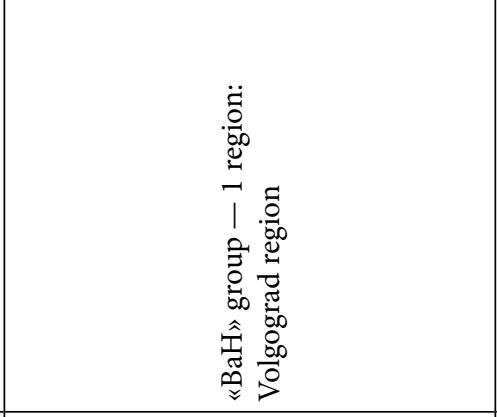 & 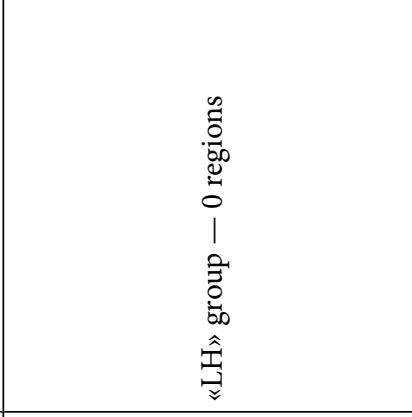 \\
\hline 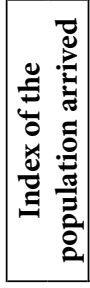 & 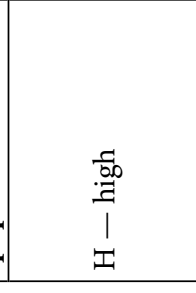 & 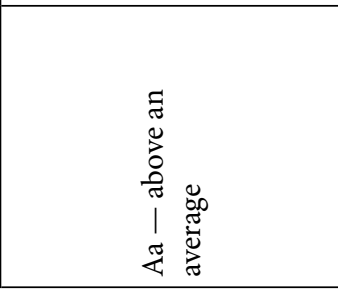 & 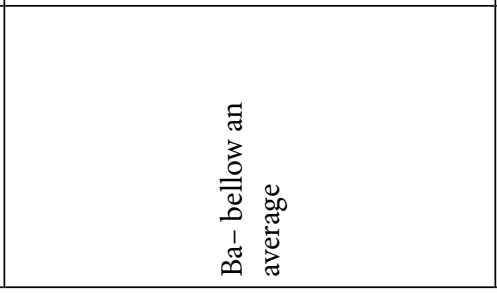 & $\begin{array}{l}\frac{z}{0} \\
1 \\
\end{array}$ \\
\hline
\end{tabular}


index and above an average index of the population arrived: the Republic of Bashkortostan and Tatarstan, Krasnoyarsk territory, Novosibirsk, Belgorod, Leningrad areas, and the region which is poorly investing in the health care infrastructure due to the fact of the small population size, and also not so attractive to migrants from the point of view of climatic conditions - the Yamalo-Nenets Autonomous Area.

Thus, we have revealed following: in spite of the fact that the majority of migrant inflows was only into a small number of regions, and investment into the health care infrastructure was carried out unequal, in the regions were relative agreement in a share of distribution of investments into objects of the health care sphere and a share of migrants. Such a situation can be explained with population expectations at the choice of regions for planned migration.

The calculations presented above did not consider the population size but were limited only to a correlation of regional and all-Russian data on the indicators presented above. For the analysis of the providing, the population with the healthcare infrastructure facilities, the data used in the prior part of the research was correlated to the population of the region [3]. Given this the following formula was used:

$$
I_{i}^{p}=K_{i}^{r} / P^{r},
$$

where $I_{i}^{p}$ - an index of i-indicator; $K_{i}^{r}-$ a region indicator; $P^{r}$ - the population size of a region.

Having calculated an indicator according to the formula (3), we have received the data of the providing with the health care infrastructure facilities the population living in the certain territory. Moreover we made calculations for the same five indicators of the statistical reports, which are presented above. To finish the calculation the integrated index was offered (see 4).

Under an index of provision the population with the healthcare infrastructure facilities we decided to consider the average indicator:

$$
I_{p h}^{p}=\frac{I_{1}^{p}+I_{2}^{p}+I_{3}^{p}+I_{4}^{p}+I_{5}^{p}}{5},
$$

where $I_{p h}^{p}-$ an index of the providing the population with the healthcare infrastructure facilities; $I_{1}^{p}-$ an index of the providing the population with the outpatient clinics; $I_{2}^{p}-$ an index of the providing the population with hospital beds; $I_{3}^{p}$ - an index of the providing the population with hospitals; $I_{4}^{p}$ - an index of the providing the population with the first-aid stations; $I_{5}^{p}-$ an index of the providing the population with the institutions that administer medical aid to the population.
At the stage of research considering the population size in the regions we by analogy with the previous stage carried out two-dimensional group of regions of the Russian Federation according to the indicators of the population arrived and health care for 2011, having received less safe picture, than the earlier one (tab. 2).

As shown in Table 2, the high providing the population with healthcare infrastructure facilities was observed only in the Nenets Autonomous Area and in the Magadan region, i.e. in the regions which are included into the group with a low index of the population arrived. It is natural that in the first research the Nenets Autonomous Area where only $0.02 \%$ of inhabitants of the Russian Federation, was included into the group with low investments into the healthcare sphere. The safest picture is in the Far East federal district where 8 regions had an index of the providing the population with the healthcare infrastructure facilities above an average and one region had a high index. The most attractive for migrants is the central federal district. The number of the population arrived in 2011 is nearly $24 \%$ from all-Russian. But in all its regions it had an index of the providing the population with the healthcare infrastructure facilities below an average. The range of variation of the index of the providing the population with the healthcare infrastructure facilities is from 0.252 in the Nenets Autonomous Area up to 0.027 in the Leningrad region.

The assessment has shown that the providing the population with the healthcare infrastructure facilities by regions was much lower than its development. The regions with indexes of the providing the population with objects of the healthcare sphere at low level and below an average level appeared to be less by 10 than regions with an appropriate level of development of the healthcare sphere.

The analysis has shown that in all 10 regions experiencing the greatest migrant inflows (including 6 most safe according to the first stage of our research: Krasnodar territory, the Moscow, Sverdlovsk and Tyumen areas, Moscow and St. Petersburg) the providing the population with healthcare infrastructure facilities is below an average. In the 15 of 18 regions having the population arriving above an average, the index of providing the population with healthcare infrastructure facilities is below an average and in one region - low.

In 23 regions, the index of providing the population with healthcare infrastructure facilities was above, than the index of the population arrived. Moreover, all these regions had indicators of the 


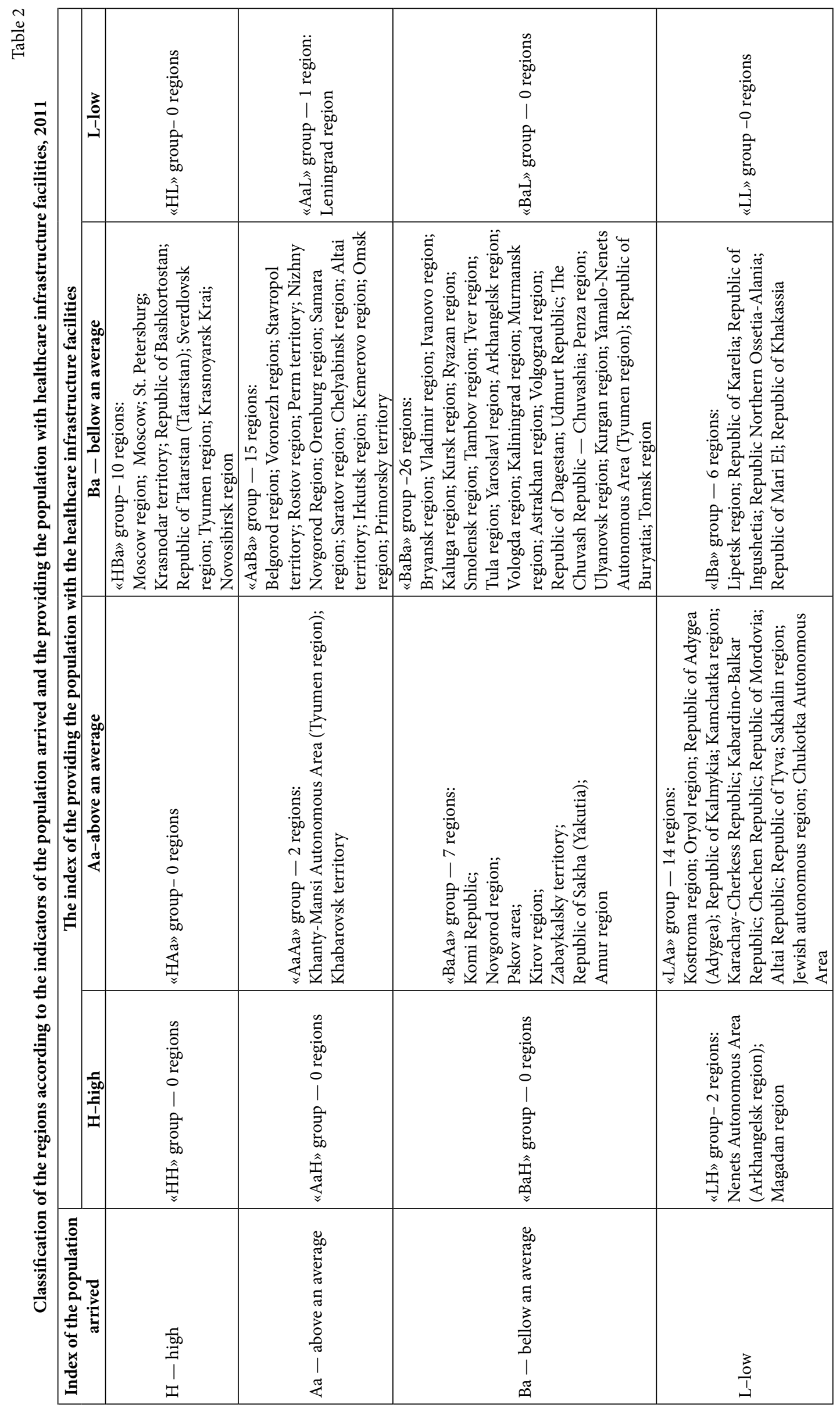




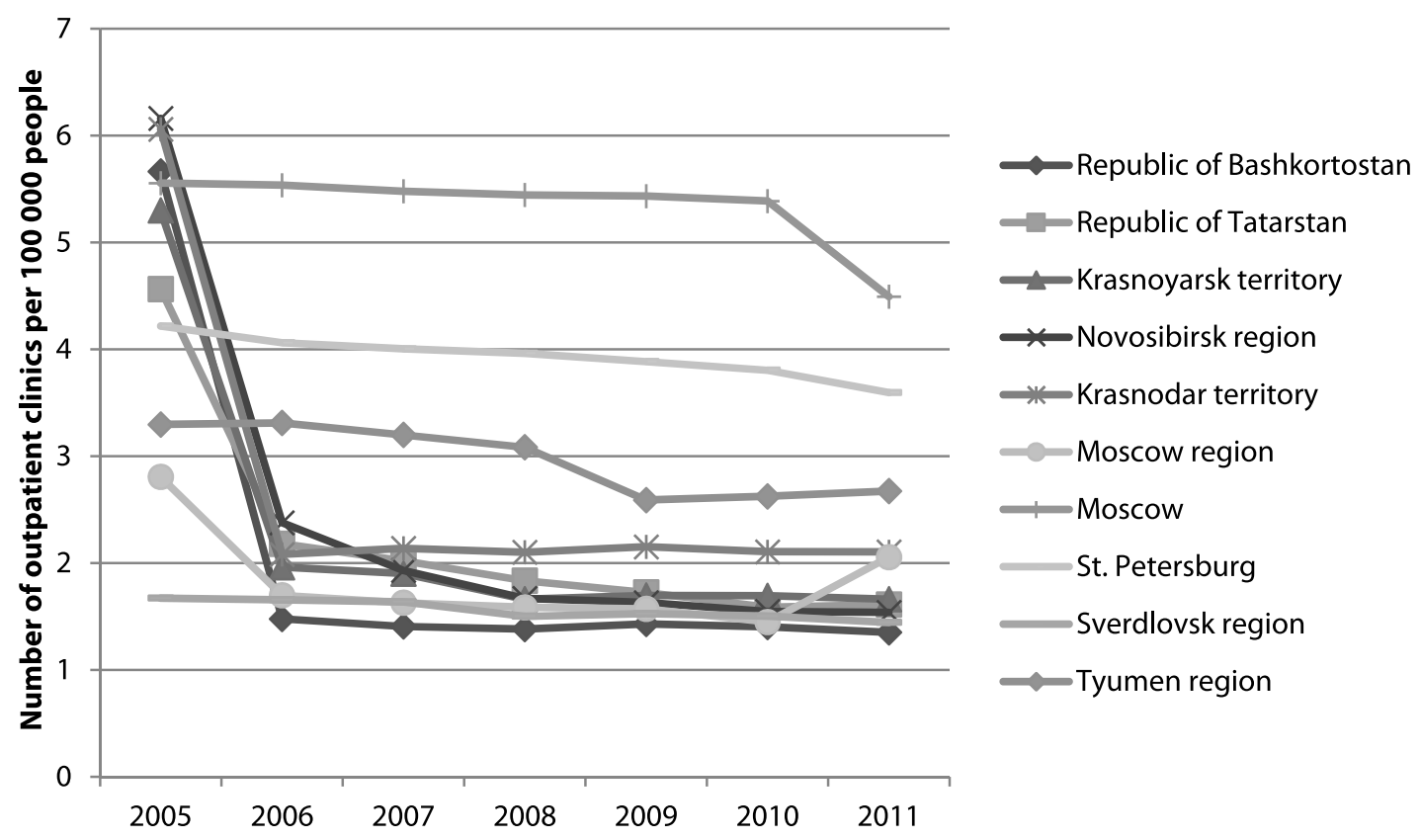

Fig. 1. Changing the number of outpatient clinics per 100000 people in the regions of the Russian Federation with a high index of the arrived population for the period from 2005 up to 2011

population arrived below average. The most of all such areas are in the following federal districts: North Caucasian -4 out of 7 and in Far East -6 out of 9 .

And only in the 28 regions (that is in $1 / 3$ ), indicators of the providing the population with infrastructure objects of the healthcare sphere were approximately corresponded to a number of the population arrived. Moreover in the 26 regions both indicators were below an average.

Thus, the high differentiation in the providing the population of the Russian Federation with the objects of the healthcare sphere was revealed. It partially correlated to the population size but did not take into consideration the distribution of regions according to the indicators of the population arriving. In other words in the issues of investment into the healthcare infrastructure facilities in 2011, the potential population and the migrant inflows was poorly taken into account. As a result of the competition for access to the health care infrastructure facilities in the most attractive regions to migrants has become tougher by that worsened the conditions of the local population.

At the following stage of the research, the 10 regions being characterized as the most popular for the migration, but having the providing the population with healthcare infrastructure facilities below an average were chosen. At this stage, the following research objective was set: to analyze the dynamics of indicators according to the existence of the number of outpatient clinics, hospital beds, hospitals, first-aid stations, and institutions providing medical assistance to the population.
Due to the lack of investment for maintenance and development of the basic health funds and medical equipment [3] from the end of the 90th up to 2006 in the majority of regions of the Russian Federation under the presence of cost minimization the policy of reduction of the health care infrastructure facilities was actively pursued. In research, the period from 2005 up to 2011 was taken (fig.1).

As shown in the figure 1, for 2005-2011 almost in all considered regions (except for Sverdlovsk and Moscow areas) there was an essential reduction of outpatient clinics in terms of the population size. Growth of this indicator in the Moscow region in 2010 partially compensated its falling in Moscow. The biggest ratio of the outpatient clinics to the population size throughout all considered period was in the cities of federal importance - Moscow and St. Petersburg. It is slightly less, than in the cities of federal importance, but much more than in other regions - in the Tyumen region. The least is in the Republic of Bashkortostan.

The number of hospital beds is considered to be one of the most important indicators of an assessment of healthcare infrastructure facilities. In the Soviet Union, the average providing with hospital beds was about 1200 per 100000 people. The need in having hospital beds is a multi-factor issue: the level of the health care to the population in outpatient clinics, climatic conditions of accommodation, density of settling people, the equipping the medical institutions with medical technique, etc. From the WHO point of view from 200 to 600 


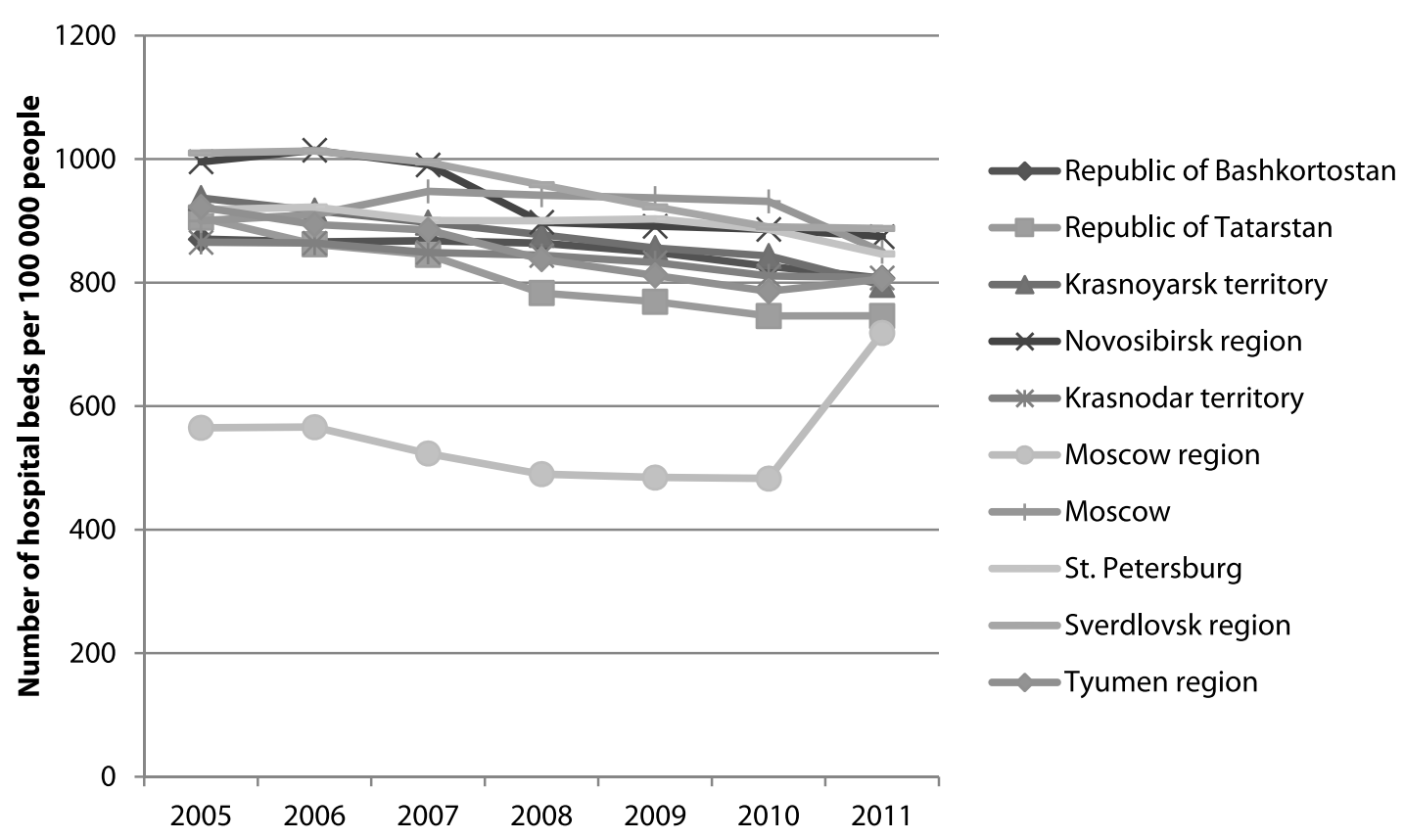

Fig. 2. Changing the number of hospital beds per 100000 people in the region of Russia Federation with high index of the arrived population for the period from 2005 to 2011
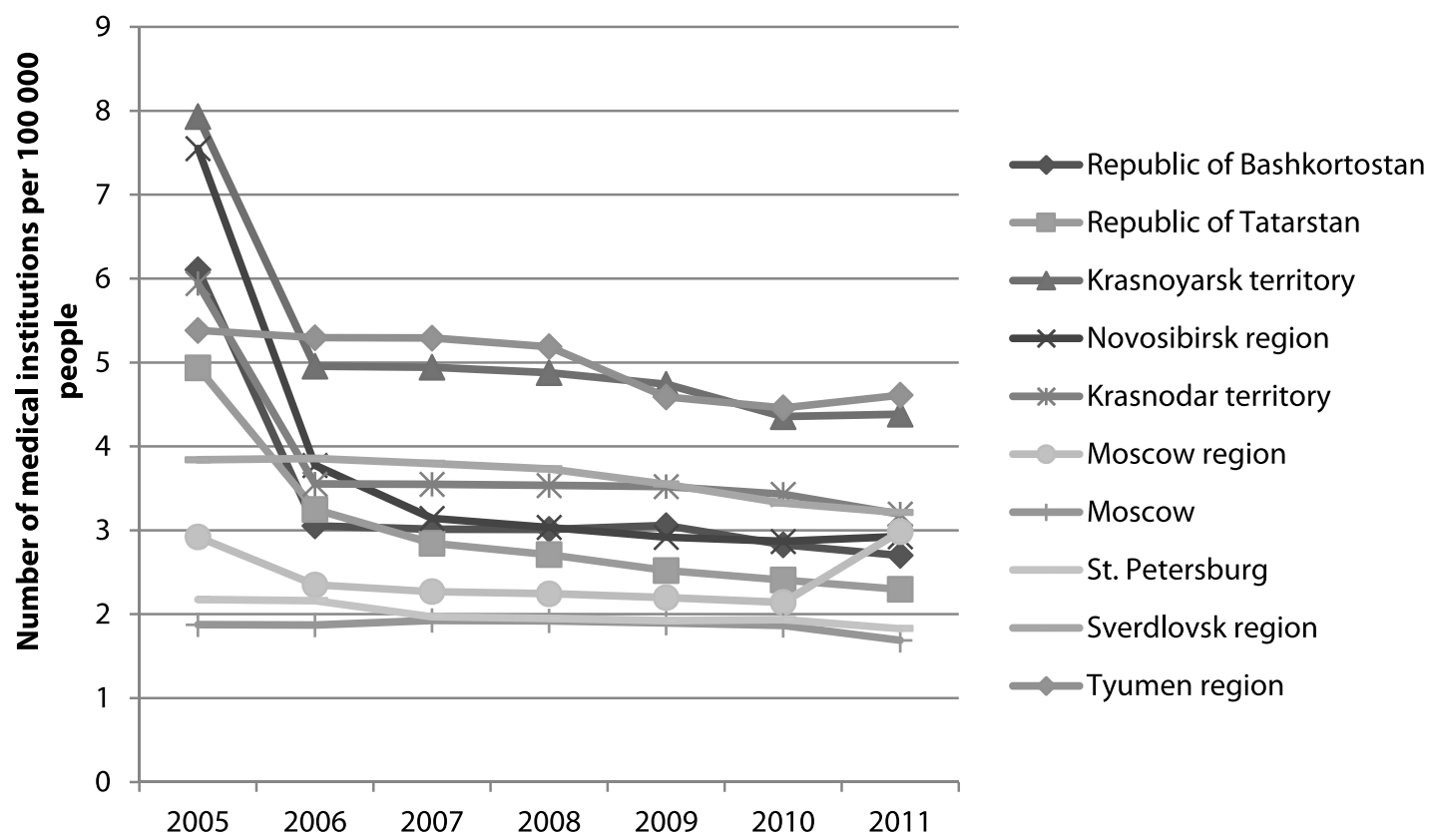

Fig. 3. Changing the number of hospitals per 100000 people in the regions of Russia Federation with a high index of the arrived population for the period from 2005 to 2011

hospital beds per 100000 population is considered to be the most effective option [1]. Note that in all 10 regions being considered there were more beds by 2011 than the recommended indicator (fig. 2) and only in the Moscow region this indicator corresponded to WHO recommendations from 2005 to 2010.

According to normative documents [4], the quantity of beds is defined as follows:

$$
K=\frac{N_{b / d} \times P}{1000 \times A},
$$

where $K$ is a standard number of beds; $N_{b / d}-$ the number of bed-days per 1000 people (the approved normative standard for the territorial program of the state guarantees is equal to a number of hospitalization per 1000 inhabitants for intermediate term care of a patient in a hospital); $P-$ population size; $A$ - average annual occupation of a bed.

As shown in the formula (5), it is possible reduction of a normative indicator of the number of beds in the following situations: firstly, in case of reduction of level of hospitalization, i. e. reduc- 


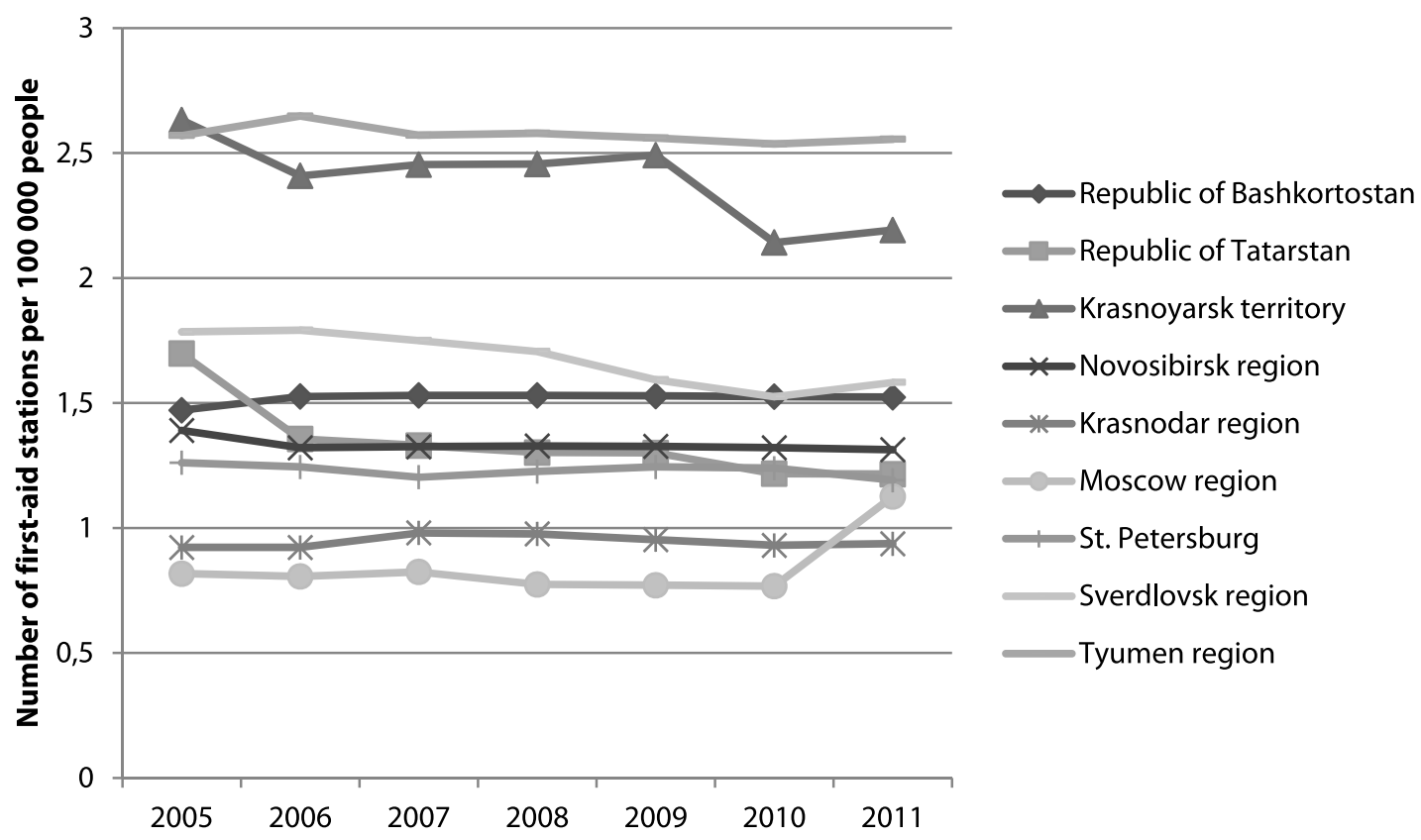

Fig. 4. Changing the number of first-aid stations per 100000 people in the regions of Russia Federation with a high index of the arrived population for the period from 2005 to 2011

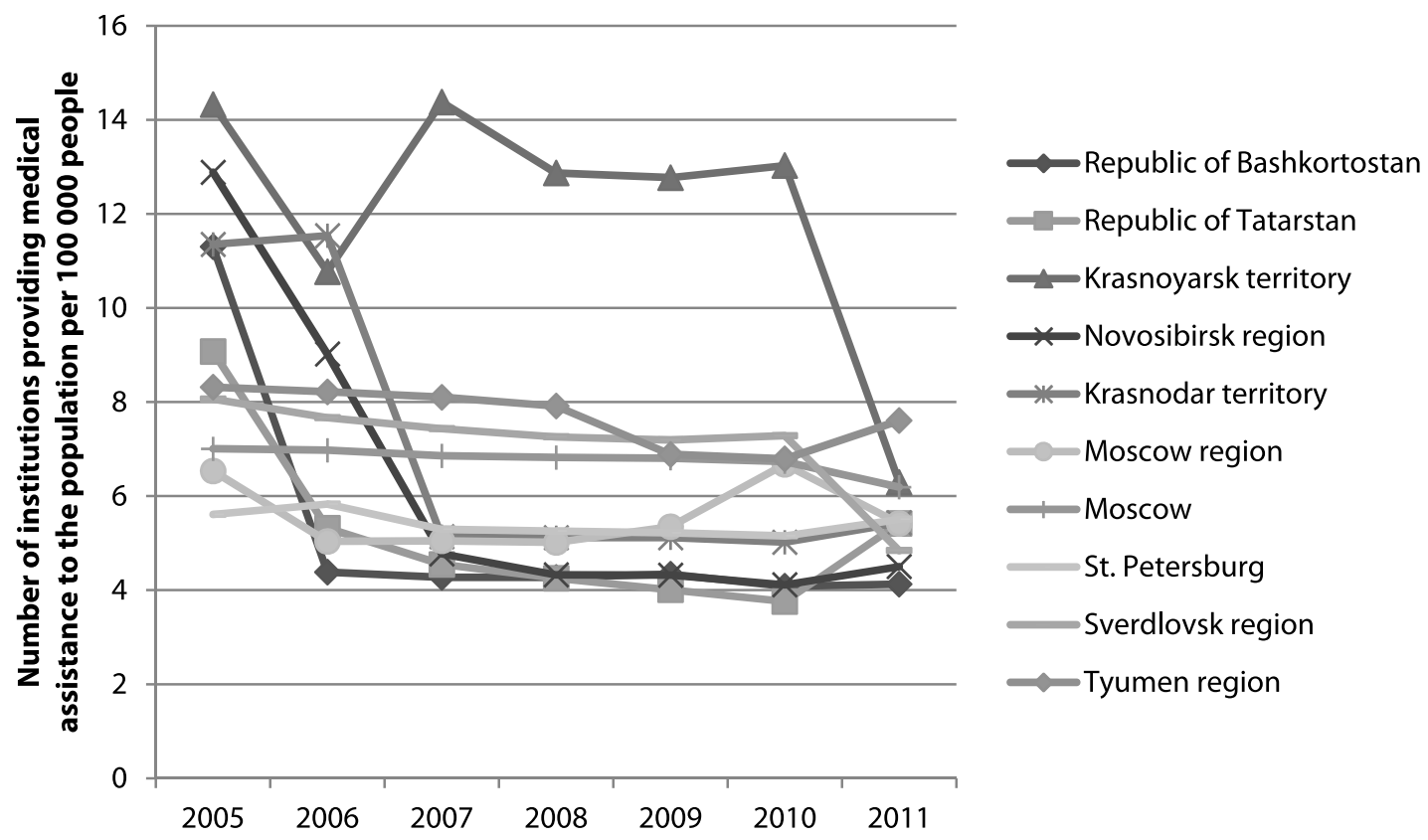

Fig. 5. Changing the number of institutions providing medical assistance to the population per 100000 people in the regions of the Russia Federation with a high index of the arrived population for the period from 2005 to 2011

tion the sickness, or number of addresses; secondly, when growth of job for outpatient clinics (but as shown in fig. 1, their quantity also were reduced); thirdly, when reduction of time of the presence of patients in hospitals; fourthly, when change structure of sickness (because the stay duration in a hospital is defined also according to the specifics of a disease).

As shown in figure 3 , the number of hospitals per 100000 people also decreased in all explored regions. The comparative analysis of a change of the number of hospital beds (fig. 2) and the number of hospitals (fig. 3) showed when the number of hospitals decreases the number of hospital beds decreases as well.

As shown in the figure 4, the considerable reduction of the number of first-aid stations per 100 000 people was in none of the regions. That indirect indicator shows that the population did not become to be healthier, and the number of calls to an emergency medical service did not decrease. In the Moscow region, there was even growth of a number of these stations. 
The figure 5 shows a general characteristic of change of the number of healthcare infrastructure facilities per 100000 people in the 10 regions being under consideration.

As shown in the figure 5, sharp decrease of the providing the population with institutions providing medical assistance to the population occurred in the following regions: in the Republic of Tatarstan and Bashkortostan in 2005-2006, in the Novosibirsk region in 2005-2007, in Krasnodar territory in 2006-2007, in Krasnoyarsk territory in 2005-2006 and repeatedly in 2010-2011, in Sverdlovsk region in 2010-2011. As a whole in all regions being under consideration except for the Tyumen region the tendency to averaging of this indicator was observed.

As showed the analysis, in ten regions having the highest rates of population migration con- siderable differentiation in security of the population with health care infrastructure facilities was originally observed, but for the period under review there was a data smoothing of indicators and their reduction that corresponded to the policy of optimization of expenses in the healthcare sphere.

Now, it is possible to draw the following conclusion: the policy of optimization of the expenses pursuing in the healthcare sphere in the last decades leads to the equalizing the territories in questions of availability of objects of the healthcare sphere, but thus it make the conditions of the local population worse and does not consider prospects of these territories' development. The territories most attractive to migrants are in the worst situation at such conditions.

\section{References}

1. Doklad VOZ o sostoyanii zdravookhraneniya v mire [The WHO Report on the Health Care Condition in The World]. (2010). Available at: http://www.who.int/whr/2010/whr10_ru.pdf (date of access: 11.01.2013).

2. Yedinaya mezhvedomstvennaya informatsionnaya sistema [United Interdepartmental Information System]. Available at: http://www.fedstat.ru/indicators/start.do (date of access: 24.10.2012).

3. Yemelyanov O. V., Kudryavtsev Yu. S., Filonova O. L. (2006). Rezultaty analiza parka meditsinskogo oborudovaniya i optimizatsii metodov ego vosstanovleniya [Results of the Analysis of the Medical Equipment Stock and Optimization of Methods of Its Restoration]. Vestnik aritmologii [Bulletin of Arrhythmology], 41, 68-71.

4. Pismo Ministerstva zdravookhraneniya I sotsialnogo razvitiya Rossiyskoy Federatsii ot 17 dekabrya 2010 g. № 20-2/10/2$12028 « \mathrm{O}$ formirovanii i ekonomicheskom obosnovanii territorialnoy programmy gosudarstvennykh garantiy okazaniya grazhdanam Rossiyskoy Federatsii besplatnoy meditsinskoy pomoshchi na 2011 g.» (Prilozheniye 4) [Information Letter of Ministry of Health and Social Development of Russian Federation of December 17, 2010 No 20-2/10/2-12028 «On Organization and Economic Case of the Territorial Program of the State Guarantees of Rendering to Citizens of the Russian Federation of the Free Medical Care for 2011» (Appendix 4)] Dostup iz sprav.-pravovoy sistemy «Konsultantplyus» [Available at the legal reference system «Consultant Plus»], (date of access: 10.12.2012).

5. Chereshnev V.A., Tatarkin A.I. (2007). Sotsialno-demograficheskaya bezopasnost regionov Rossii: metodicheskiye aspekty, sostoyaniye, tendentsii [Socio-Demographic Safety of Regions of Russia: Methodical Aspects, Condition, Tendencies]. Ekonomika regiona [Economy of Region], 4, 9-26.

\section{Information about the author}

Bedrina Yelena Borisovna (Yekaterinburg, Russia) - PhD in Economics, Associate Professor at the Chair for International Economics, Ural Federal University named after the first President of Russia B.N. Yeltsin (Lenina Av. 56 - 216, phone: +79221055965, e-mail: Bedrina1967@mail.ru).

Publication was prepared within the cross-disciplinary project No. 12-M-127-2049 «Entropy-probabilistic approach to the description of risk, degradations of sustainable development of critical infrastructure networks (on the example of power and communication information systems of the Ural Federal District)» and grant of Russian Foundation for Humanities (the project No. 12-02-00307a « Scientific and methodical framework for the assessment of quality of working life of the population of regions of Russia». 